\title{
Analysis of the invasion of water lilies (Eichhornia crassipes (Mart) Solms) in the Cointzio dam, Michoacán, Mexico
}

\author{
Vera-Vargas, Omar R. ${ }^{1}$; Prado-Hernández, Jorge V. ${ }^{2}$; Reyes-López, Delfino ${ }^{3}$; Pascual-Ramírez, Fermín ${ }^{4}$ \\ ${ }^{1}$ Universidad Nacional Autónoma de México Escuela Nacional de Estudios Superiores Unidad \\ Morelia, Morelia, Michoacán, Mexico. ²Universidad Autónoma Chapingo Departamento de \\ Suelos, Texcoco, México. ${ }^{3}$ Benemérita Universidad Autónoma de Puebla, Facultad de Ingeniería \\ Agrohidráulica, Teziutlán, Puebla, Mexico. ${ }^{4}$ Universidad Nacional Autónoma de México Instituto \\ de Investigaciones en Ecosistemas y Sustentabilidad, Morelia, Michoacán, Mexico.
}

*Corresponding Author: fpascualragmail.com

\begin{abstract}
Objective: to analyze the growth dynamics of the water lily (Eichhornia crassipes) in the Cointzio dam due to the water availability.

Design/Methodology/Approach: a monthly series of 45 Sentinel 2 and Landsat satellite images were used, with which the percentage of invasion of the water lily in the total area of the reservoir was calculated. The relative coverage of the lily was analyzed looking for growth patterns over time, as well as the precipitation data, total reservoir area over time, and water storage data for the 2010-2020 period to broaden its context.

Results: Three ascending and two descending patterns of the water lily coverage were identified; a 15-month upward growth pattern with slight inland slope changes; decreasing patterns are associated with decreased water storage. The largest lily covers were found in critical storage stages during the 2010-2020 period.

Study limitations/implications: faced with climate change conditions, the filling pattern of the dam could change, aggravating problems related to the water supply.

Conclusions: containment/mitigation efforts have a reduced effect because the lily easily recovers the covered area, growing about 400\% between October 2017 and June 2018, therefore it is necessary to implement a containment strategy using the biophysical interactions of the basin in conjunction with social, political, economic and governance interactions.
\end{abstract}

Keywords: water management, social-ecological systems, available water, remote sensing, socio-hydrology.

\section{INTRODUCTION}

The growth of large population centers reauires actions to provide basic senvices so (Mekonnen \& Hoekstra, 2016; Vollmer et al., 2018). In Mexico, the most frequent water sources for domestic use are deep wells (Ríos, Prado-Hernández, Romero-Bautista, Reyes-López, \& Pascual-Ramírez, 2019), to a lesser extent surface 
water is used through the construction of warehousing structures. Surface water reservoirs face problems due to the degradation of their catchment basins, which facilitates the spread of aquatic plant species that alter the functioning of the ecosystems; One of these species is the water lily (Eichhornia crassipes), which easily adapts to various environmental conditions due to its capacity to absorb nutrients (Ting, Tan, Salleh, \& Wahab, 2018). This causes damages such as water loss, flow retardation, obstruction of pipeline infrastructure, health hazards due to accumulation of human disease vectors and alteration of the physical-chemical characteristics of water and hydraulic soil (Ali \& El-Din Khedr, 2018); Furthermore, it decreases the available oxygen in the water and reduces sunlight passage which that causes the death of organisms in the aquatic ecosystems (Keller \& Lodge, 2009).

The water lily reproduces both, sexually and asexually. The first has high success levels, generates up to 2,534 seeds per $\mathrm{m}^{2}$ and their germination rate is $54.17 \%$ in a maximum period of three days (Gunnarsson \& Petersen, 2007; Thamaga \& Dube, 2018), even despite the high flowers proportion lost by the species that inhabit the environment in which it develops (Albano Pérez, Coetzee, Ruiz Téllez, \& Hill, 2011). Regard their asexual reproduction, it can double its biomass within two weeks; Thus, 10 plants can in eight months produce 655,360 new plants, reaching a surface area of half a hectare (Thamaga \& Dube, 2018). Therefore, the objective of this work was to analyze the growth dynamics of the water lily in the Cointzio dam in Michoacán, Mexico, whose use is to supply water for agricultural and domestic use in the city of Morelia.

\section{MATERIALS AND METHODS}

The research was carried out in the Cointzio dam, north of the state of Michoacán $\left(19^{\circ}\right.$ $24^{\prime} 30^{\prime \prime}$ and $19^{\circ} 38^{\prime} 30^{\prime \prime} \mathrm{N}$ and $101^{\circ}$ $08^{\prime} 30^{\prime \prime}$ and $\left.101^{\circ} 33^{\prime} 00^{\prime \prime} \mathrm{W}\right)$. The dam has a $300 \mathrm{~m}$ long crown $8 \mathrm{~m}$ wide, $46 \mathrm{~m}$ high at the curtain, with an water mirror extension of 500 ha, and a useful storage volume of $65.61 \mathrm{~h} \mathrm{~m}^{3-1}$ (CONAGUA, 2018). The meteorological data from the observatory 16081 'Morelia' of the National Meteorological Service (SMN, 2020), reports annual precipitation of $795.6 \mathrm{~mm}$, mean annual temperature of $19{ }^{\circ} \mathrm{C}$, mean minimum temperature of $10.4{ }^{\circ} \mathrm{C}$ and average maximum temperature of $27.5^{\circ} \mathrm{C}$. A set of 45 satellite images from November 2016 to July 2020 (Table 1) were used, these were obtained by the Sentinel2B (MSI sensor) and the Landsat 8 (OLI sensor) satellites. The images from February 22 and August 17, 2017, as well as February 24, August 23 and December 13, 2019, were Landsat (Table 1).

The satellite images, with radiometric and geometric corrections, were downloaded from their websites. The QGIS 3 software was used to delimit the dam reservoir based on the water area. The Semi-Automatic Classification Plugin tool classified the areas of water and aquatic vegetation, these were rectified using spectral patterns associated with water and vegetation (Pascual Ramírez et al., 2010). After classification, the data matrices were converted to vector format to calculate the area and percentage of invasion of the water lily in the reservoir.

Using linear regression techniques, explanatory patterns of the progress of lily coverage in the dam were sought, using the determination coefficient and the slope of the line, as fit descriptors. The total coverage area of the dam over time and the reported precipitation values were analyzed; The data of the storage volumes and water extraction of the dam during the 2010-2020 period were also used (CONAGUA, 2020).

\section{RESULTS AND DISCUSSION}

The minimum coverage of the lily in the dam vessel was during November 2016 (Table 2), a similar value was recorded during April 2017 (2.15\%). It is worrying the number of months during which the lily coverage exceeded $50 \%$, such as the period from June to August 2018 and, during 2019, March, July, August and October;

\begin{tabular}{c|c|c|c|c}
\multicolumn{2}{c}{ Table 1. Satellite images used. } & \multicolumn{1}{l}{ Date } & Date \\
\hline Date & Date & Date & D & D \\
\hline $11 / 11 / 2016$ & $17 / 08 / 2017$ & $30 / 05 / 2018$ & $24 / 02 / 2019$ & $16 / 11 / 2019$ \\
\hline $21 / 12 / 2016$ & $12 / 09 / 2017$ & $24 / 06 / 2018$ & $26 / 03 / 2019$ & $13 / 12 / 2019$ \\
\hline $10 / 01 / 2017$ & $27 / 10 / 2017$ & $19 / 07 / 2018$ & $20 / 04 / 2019$ & $25 / 01 / 2020$ \\
\hline $22 / 02 / 2017$ & $16 / 11 / 2017$ & $18 / 08 / 2018$ & $15 / 05 / 2019$ & $24 / 02 / 2020$ \\
\hline $10 / 03 / 2017$ & $26 / 12 / 2017$ & $22 / 09 / 2018$ & $14 / 06 / 2019$ & $25 / 03 / 2020$ \\
\hline $30 / 04 / 2017$ & $15 / 01 / 2018$ & $07 / 10 / 2018$ & $09 / 07 / 2019$ & $24 / 04 / 2020$ \\
\hline $15 / 05 / 2017$ & $04 / 02 / 2018$ & $28 / 11 / 2018$ & $16 / 08 / 2019$ & $25 / 05 / 2020$ \\
\hline $09 / 06 / 2017$ & $16 / 03 / 2018$ & $21 / 12 / 2018$ & $27 / 09 / 2019$ & $15 / 06 / 2020$ \\
\hline $19 / 07 / 2017$ & $30 / 04 / 2018$ & $20 / 01 / 2019$ & $07 / 10 / 2019$ & $13 / 07 / 2020$ \\
\hline
\end{tabular}




\begin{tabular}{l|c|c|c|c|c}
\multicolumn{1}{|l|}{ Table 2. Relative lily coverage in the dam. } \\
\hline \multicolumn{1}{c|}{ Month } & 2016 & 2017 & 2018 & 2019 & 2020 \\
\hline January & & 10.36 & 36.12 & 43.12 & 35.63 \\
\hline February & & 16.16 & 42.61 & 45.56 & 39.27 \\
\hline March & & 10.39 & 35.77 & 50.61 & 35.00 \\
\hline April & & 2.15 & 34.83 & 49.17 & 32.26 \\
\hline May & & 9.56 & 46.39 & 43.94 & 25.00 \\
\hline June & & 5.46 & 56.19 & 42.85 & 20.52 \\
\hline July & & 4.42 & 50.00 & 50.00 & 33.05 \\
\hline August & & 15.50 & 51.21 & 51.00 & \\
\hline September & & 13.19 & 37.08 & 49.50 & \\
\hline October & & 12.00 & 46.76 & 50.00 & \\
\hline November & 2.10 & 19.41 & 43.57 & 49.00 & \\
\hline December & 5.56 & 34.32 & 44.31 & 46.68 & \\
\hline
\end{tabular}

From all cases, the highest was during June 2018, when the lily coverage reached $56.19 \%$ of the reservoir surface. If coverage is considered greater than or equal to $40 \%$, then, the entire 2019 was above this threshold; while, during 2018, only three months registered values below 40\% (March, April and September), with values (35\%) very close to the proposed threshold.

In fact, the annual average coverage during 2018 and 2019, exceeded 40\%, which in ecological terms is worrying, since it damage the freshwater fauna by limiting oxygen availability for vital activities (Keller \& Lodge, 2009), which affects fishing and recreational activities.

The results of the relative lily coverage were plotted on a continuum throughout the 45 months of the analysis, together with the precipitation data from the beginning of the assessment until September 2019 (Figure 1). Three growth regions two of decreased coverage were located, the first growth series began in November 2016 and lasted until February 2017, where a linear adjustment was made, with an $\mathrm{R}^{2}$ of 0.99 and a slope of 4.7. As of February, a decrease was observed, due to containment and mitigation practices that led, together with the decrease in storage volume, to a minimum, observed in April.

The second growth series is the most alarming, it began in October 2017 and lasts until February 2018, these five months of uninterrupted growth caused high levels of coverage and that stabilized in their upper part, with a linear $\mathrm{R}^{2}$ adjustment of 0.94 and a 7.79 slope, which denotes the intense growth in the area occupied by lily pads during that period. There is another growth period over the previous one from March to June 2018, which adjusts to a line with an $R^{2} 0.87$ and slope of 7.28 . These two growth periods can be coupled in one, from October 2017 to June 2018, adjusted to a line with $\mathrm{R}^{2}$ of 0.79 and slope of 4.31. A period of intense growth that goes from April 2017 to June 2018 is noticeable, with slight changes in its slope between July and October 2017, and April 2018; This prolonged growth from the beginning to the end of the analysis period can be adjusted to a line with $\mathrm{R}^{2}$ of 0.9 and slope of 0.65 . The stated above highlights the importance of the mitigation and containment practices of the lily in the dam, since, when left, in short time it reaches high coverage rates due to its reproductive success, both sexual and asexual (Gunnarsson \& Petersen, 2007; Thamaga \& Dube, 2018).

As shown in Figure 1, there are periods in which the lily cover dynamics on the dam is associated with precipitation presence / absence. For example, during the March-April-May period, low lily covers were present while the highest growth rates were observed from MayJune, the period with the highest rainfall in each of the analyzed years.

There are two important decline periods, the first of which goes from June to September 2018, which was adjusted to a line with $\mathrm{R}^{2}$ of 0.79 and slope of -5.61 ; the second decline period goes from February to June 2020, which was adjusted to a line with $R^{2}$ of 0.98 and slope of -4.75 .

The reservoir area depends of the water inlets and outlets in the system during May, which recorded the minimum occupied area in the dam during 2017 and 2018, and changed to June in 2019 and 2020 (Figure 2). The dam was full during September 2017 and 2018, occupying areas greater than 500 ha; However, in 2019, the storage of the dam decreased, since its occupied area was

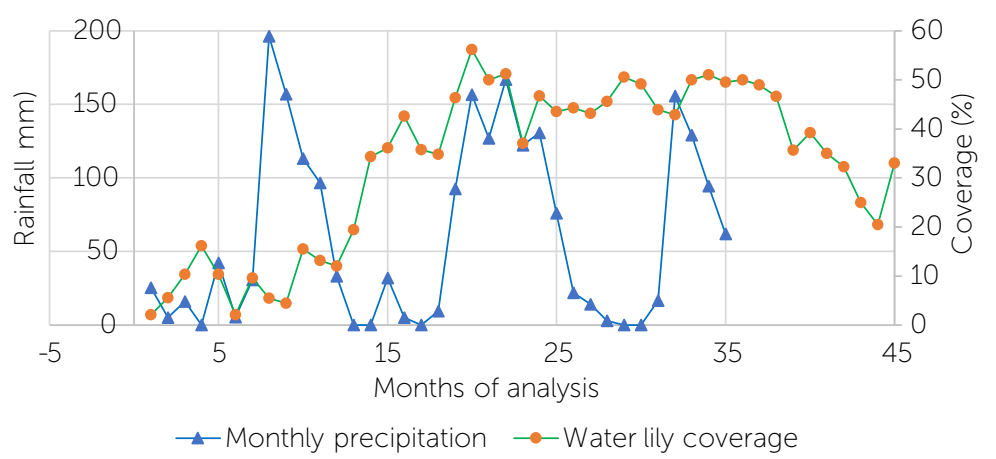

Figure 1. Time series of the coverage and precipitation. 


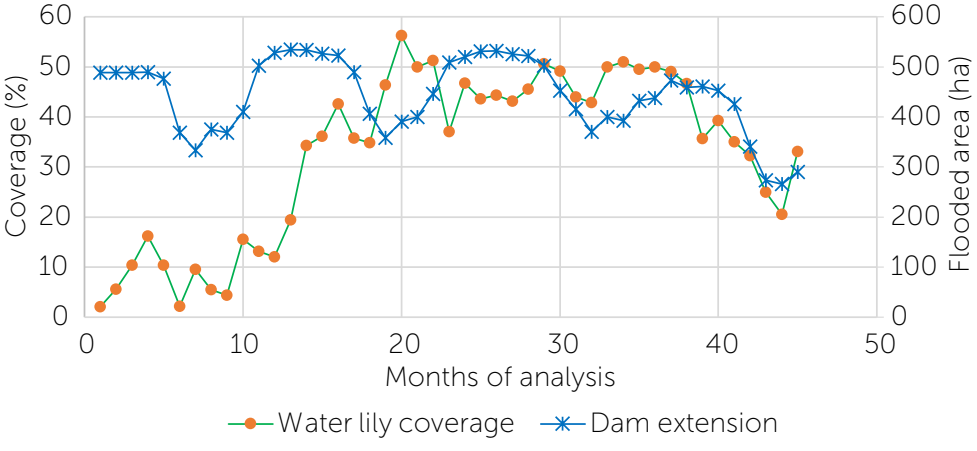

Figure 2. Time series of lily coverage and precipitation.

432 ha during September and its maximum reached in November, with 473 ha.

It is interesting to observe that as the area of the dam decreased, the relative lily cover also decreased; In fact, as of November 2019, a downward trend is observed until June 2020, a behavior coupled with an area decrease (and consequently storage) and a decrease in the percentage of lily coverage in the body of water.

By the end of the analysis period, between November 2019 and June 2020, the relation between coverage and area occupied by the dam has a linear behavior with an $\mathrm{R}^{2}$ of 0.81 and slope of 8.06 , which leads to deduce that the relative coverage is associated with the area covered by the body of water. It has been observed that as the water level in the dam decreases, the lily accumulates on the periphery during the dry season months (midFebruary to mid-May), when the second moment of intense water extraction occurs. As it accumulates on the walls, several specimens die, at that moment local inhabitants take chance to carry out mitigation works by setting the dry lily on fire; However, their seeds remain in the surrounding environment and due to their longevity (latency greater than five years), the persistence of the seed is a factor that influences the long-term control and eradication of it (Albano Pérez et al., 2011). As soon as the first rains occur (May-June), the storage volume increases, and the coverage increases, thus achieving the conditions for the germination of the seeds that remain on the edges of the dam.

From what is shown by Figure 1 and Figure 2, during 2018, there was little attention to the water lily and, therefore, it had a long upward curve, regardless of the intensity of the rain events, extraction or filling of the dam. This situation may be aggravated by the climate change effects, since the incidence of atypical rains during the dry season can generate intense periods of heatwave (Maass et al., 2018) which forces the use of extraordinary volumes of water in the filling of the dam, so water availability will decrease in the short term.

The projected water demand for 2030 for the city of Morelia, which is currently $4.1 \mathrm{~m}^{3} / \mathrm{s}$, is expected to increase to $4.3 \mathrm{~m}^{3} / \mathrm{s}$ (CONAGUA, 2010); With the enormous pressure in the water resource and changes in land use, it is estimated that the La Mintzita spring will decrease its water supply; while the abatement of deep wells will create greater dependence on the dam's water.

In the analysis of the monthly storage volume during the 2010-2020 period (2020 only January-March), a downward trend was observed, although an explanatory line cannot be adjusted, the observed slope (data not shown) was negative. To facilitate the analysis, the reported monthly volumes were grouped and averaged by season of the year (Figure 3); In all cases, storage had a decreasing trend, with a peak in 2015 (except in winter) and a sharp decrease in the 2016-2019 period; on the contrary, in the 2010-2015 period, there was a stable slightly upward trend. During the 2010-2015 period, the average storage in all stations was above 50 $\mathrm{h} \mathrm{m}^{3-1}$, even during the winter it was above $80 \mathrm{~h} \mathrm{~m}^{3-1}$. During the 2016-2019 period, storage during summer and autumn was between $30 \mathrm{~h} \mathrm{~m}^{3-1}$ and $70 \mathrm{~h} \mathrm{~m}^{3-1}$, the minimum values of the previous period were close to the maximum records in this period, which shows a strong water availability deficit in the period from 2016 to 2020.

The growth of the lily occurred in one of the most sensitive periods for the storage in the dam (2017-

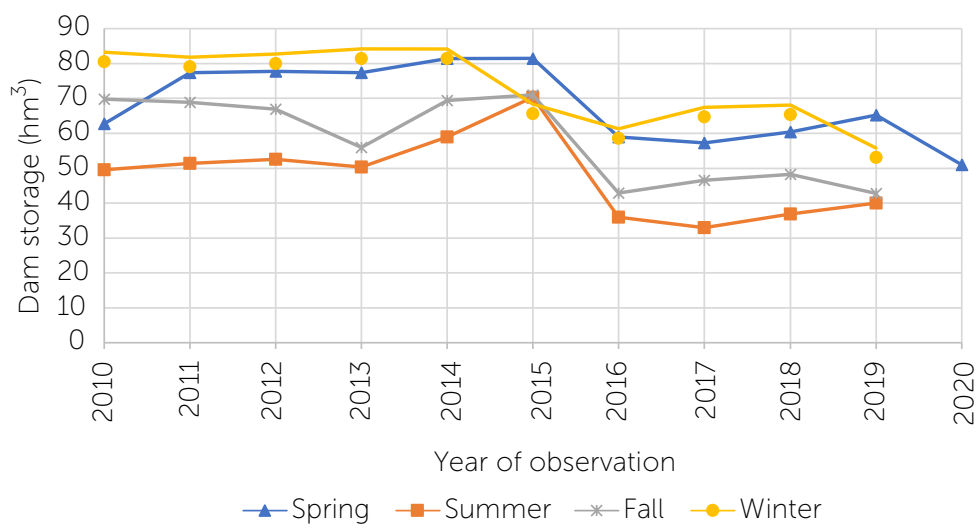

Figure 3. Average water storage by season 
2018), which marks the importance of containing it and other threats to the water sustainability of the storage system. The intensity of the lily coverage was particularly intense during the period in which the lowest storages of the 2010-2020 series were reported. The potential influence of climate change on world food production and access to water for domestic use has made climate variables the main concern of many studies (Yang et al., 2020); However, the role played by the invasion of aquatic species in bodies of water in which they cause significant losses due to evapotranspiration should not be overlooked (Ali \& El-Din Khedr, 2018; Anda, Simon, Soos, Teixeira da Silva, \& Kucserka, 2016), since the water lily can reach evapotranspiration levels in reservoirs 2.13 times higher than in conditions without it.

Although mitigation efforts through the extraction of the lily during the dry season contribute to reduce its impact, it is important to undertake actions that consider the basin as a fundamental work unit. Beyond this, it would be important to analyze the problem of the lily invasion in the reservoir considering the biophysical system with human interactions derived from the analysis of socioecological systems, since water dynamics is a key component in the ecosystems management, and human activities have an effect and are affected by the response of the ecosystem to these interventions (Maass, 2017). Due to this, any action to mitigate the damage caused by the water lily proliferation must be fully agreed with the actors involved in the management process, both internally and externally, throughout the basin and its users (Figure 4).

\section{CONCLUSIONS}

The water lily has high propagation rates in the Cointzio dam, the highest incidence was recorded during the period of least storage. Although mitigation work is carried out, its effect is marginal, since the plant easily recovers given the incidence of rains and the germination of surrounding seeds; This leads the lily to double the area occupied from one month to the next, the highest growth rate was from October 2017 to June 2018 , where it grew at a rate of $400 \%$, coincidentally the time of least water storage in the dam, the 20102020 period. The reduction of the affected area occurs during the dry season; however, the rainy season encourages spread. To improve water availability, it is urgent to address the problem from a comprehensive perspective, implementing a containment strategies based on biophysical interactions in conjunction with social, political, economic and governance interactions, considering local, internal and external actors to the Basin.

\section{REFERENCES}

Albano Pérez, E., Coetzee, J. A., Ruiz Téllez, T., \& Hill, M. P. (2011). A first report of water hyacinth (Eichhornia crassipes) soil seed banks in South Africa. South African Journal of Botany, 77(3), 795-800. https://doi.org/10.1016/j.sajb.2011.03.009

Ali, Y. M., \& El-Din Khedr, I. S. (2018). Estimation of water losses through evapotranspiration of aquatic weeds in the Nile River (Case study: Rosetta Branch). Water Science, 32(2), 259-275. https:// doi.org/10.1016/j.wsj.2018.08.002

Anda, A., Simon, B., Soos, G., Teixeira da Silva, J. A., \& Kucserka, T. (2016). Effect of submerged, freshwater aquatic macrophytes and littoral sediments on pan evaporation in the Lake Balaton region, Hungary. Journal of Hydrology, 542, 615-626. https:// doi.org/10.1016/j.jhydrol.2016.09.034

CONAGUA. (2010). Programa Hídrico Visión 2030 del Estado de Michoacán. México, DF

CONAGuA. (2018). Atlas del agua en México (C. N. del Agua, Ed.). México, DF: Secretaría de Medio Ambiente y Recursos Naturales.

Gunnarsson, C. C., \& Petersen, C. M. (2007). Water hyacinths as a resource in agriculture and energy production: A
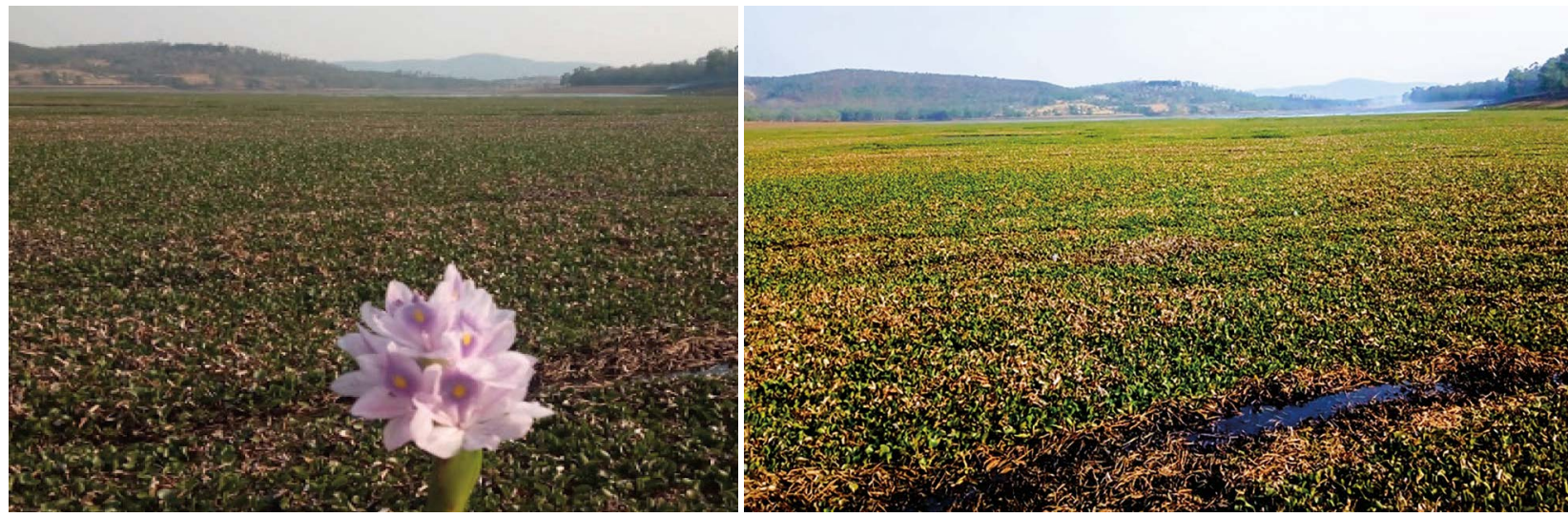

Figure 4. Water lily and invasion overview (Eichhornia crassipes (Mart) Solms) in the Cointzio dam, Michoacán, Mexico. 
literature review. Waste Management, 27(1), 117-129. https://doi.org/10.1016/j. wasman.2005.12.011

Keller, R. P., \& Lodge, D. M. (2009). Invasive Species. Encyclopedia of Inland Waters, 92-99. https://doi.org/10.1016/B978-012370626-3.00226-X

Maass, M. (2017). Integrating food-water-energy research through a socio-ecosystem approach. Frontiers in Environmental Science, 5(AUG), 1-8. https://doi. org/10.3389/fenvs.2017.00048

Maass, M., Ahedo-Hernández, R., Araiza, S., Verduzco, A., Martínez-Yrizar, A., Jaramillo, V. J., ... Sarukhán, J. (2018). Long-term (33 years) rainfall and runoff dynamics in a tropical dry forest ecosystem in western Mexico: Management implications under extreme hydrometeorological events. Forest Ecology and Management, 426(September 2017), 7-17. https://doi.org/10.1016/j.foreco.2017.09.040

Mekonnen, M. M., \& Hoekstra, A. Y. (2016). Sustainability: Four billion people facing severe water scarcity. Science Advances, 2(2), 1-7. https://doi.org/10.1126/sciadv.1500323

Pascual Ramírez, F., Paz Pellat, F., Martínez Menes, M., Palacios Vélez, E., Mejía Sáenz, E., \& Rubio Granados, E. (2010). Clasificador genérico de objetos en imágenes AVHRR. Terra Latinoamericana 28(1): 1-13

Ríos, M. J., Prado-Hernández, V., Romero-Bautista, A., Reyes-López, D., \& Pascual-Ramírez, F. (2019). Modeling water availability in the Zirahuén Lake Basin. Tecnologia y Ciencias Del Agua, 10(3), 275-288. https://doi.org/10.24850/j-tyca-2019-03-11

SMN. (2020). Información Climatológica por estado. Retrieved September 2, 2020, from https:// smn.conagua.gob.mx/es/informacion-climatologica-por-estado? estado=mich

Thamaga, K. H., \& Dube, T. (2018). Remote sensing of invasive water hyacinth (Eichhornia crassipes): A review on applications and challenges. Remote Sensing Applications: Society and Environment, 10(October 2017), 36-46. https://doi.org/10.1016/j. rsase.2018.02.005

Ting, W. H. T., Tan, I. A. W., Salleh, S. F., \& Wahab, N. A. (2018). Application of water hyacinth (Eichhornia crassipes) for phytoremediation of ammoniacal nitrogen: A review. Journal of Water Process Engineering, 22(October 2017), 239-249. https://doi. org/10.1016/j.jwpe.2018.02.011

Vollmer, D., Shaad, K., Souter, N. J., Farrell, T., Dudgeon, D., Sullivan, C. A., ... Regan, H. M. (2018). Integrating the social, hydrological and ecological dimensions of freshwater health: The Freshwater Health Index. Science of the Total Environment, 627, 304-313. https://doi.org/10.1016/j.scitotenv.2018.01.040

Yang, M., Wang, G., Ahmed, K. F., Adugna, B., Eggen, M., Atsbeha, E., ... Anagnostou, E. (2020). The role of climate in the trend and variability of Ethiopia's cereal crop yields. Science of The Total Environment, 723, 137893. https://doi.org/10.1016/j. scitotenv.2020.137893 